\title{
AGV KIBER-FIZIKAI NAVIGÁCIÓS RENDSZER
}

\section{CYBER-PHYSICAL NAVIGATION SYSTEM OF AGV}

\author{
Erdei Timotei István ${ }^{1}$, Zsolt Molnár ${ }^{2}$, Nwachukwu C. Obinna ${ }^{3}$, Husi Géza ${ }^{4}$ \\ Debreceni Egyetem, Müszaki Kar, Villamosmérnöki és Mechatronikai Tanszék, Cím: \\ 4028, Magyarország, Debrecen, Ótemetö u. 2-4; \\ Itimoteierdei@gmail.com \\ ${ }_{2}^{2}$ solt.molnar94@gmail.com \\ 3 chuchuobinna@gmail.com \\ ${ }^{4}$ husigeza@eng.unideb.hu
}

\begin{abstract}
In the XXI.st Century the application of mobile robots has a decisive role in production process, mainly in logistics \& material handling tasks. Due to globalization the intralogistics, industrial networked devices, timed processes, induced the Industry 4.0/IoT. The first step to full automation of industries will be the cyber-physical navigation system of AGVs.
\end{abstract}

Keywords: AGV, Image processing, Augmented reality; ARma; OpenCV; Timotei-Robotics

\section{Összefoglalás}

A XXI. századra a mobil robotok alkalmazása a gyártástechnológiában meghatározó szerephez jutott, a logisztikai és az anyagmozgatási feladatok tekintetében. A globalizáció következtében az intralogisztika, a hálózatba kötött ipari eszközök és az időzített folyamatok egységesen indukálták az Ipar 4.0 és az IoT megjelenését. Az AGV-k kiber-fizikai navigációs rendszere lesz a következő lépcsőfok az ipari létesítmények teljes automatizálása felé

Kulcsszavak: AGV; képelemzés; Augmented reality; ARma; OpenCV; Timotei-Robotics

\section{Bevezetés}

A megnövekedett élőmunkaidő, magával hozta arányosan a munkadíj költségek növekedését is. Ezért kiemelt prioritást kell, kapjon az anyagmozgató robotok nagyobb számban való bevonása a termelési folyamatokba.

A világon több cég is forgalmaz $A G V$ anyagmozgató robotokat, megfelelően kidolgozott technikai háttérrel. Sajnos ezen AGV-k navigációs irányító rendszere zárt „,ég specifikus” és csak önmagukkal kompatibilisek. A gyártók kihasználva ezen előnyüket, a beszerzési és telepítési költségeket magasan tartják. Ezen üzletpolitikára vezethetö vissza az AGV mobil robotok minimális jelenléte az ipari létesítményekben, az élőmunkához képest.

Az intralogisztikai feladat, amiknek egy adott AGV-nek meg kell felelnie rendkívül komplex, mivel a mindenkori termelési ciklushoz kell alkalmazkodnia, ami több szakterületet is igénybe vesz, úgy, mint informatika, rakodástechnika/szállítás és kommunikáció. Ezen területek élőmunkával történő összehangolása nagy rizikó faktort 
jelent, ami egy automatizált AGV rendszerrel minimalizálható.

A fö célkitüzésünk egy egyedi kiber-fizikai rendszer megalkotása volt, ami interaktív kapcsolatban van környezetével és az általunk megalkotott számítási rendszerrel. A vizsgálat tárgyát képezte továbbá projectünkben, hogy egy automatizált vezetésủ jármü, ami saját fejlesztésủ képfeldolgozáson alapul, Augmented Reality technikát alkalmazva, eredményesebben és költséghatékonyabban látják-e el, egy zárt, fedett területen az anyagmozgatási feladatokat, komoly „,irányítási infrastruktúra” kiépítése nélkül, szemben az „élő”munkával.

\subsection{KUKA KR5 megfogó vezérlése}

A Debreceni Egyetem Épületmechatronikai Kutatóközpont Robotlaborjába egy KUKA KR5 hegesztő robot került telepítésre/beüzemelésre.

A konstrukció maga ipari célokra lett kialakítva ívhegesztéshez, gyors és precíz mozgásra képes, relatíve nagy munkaterület mellett [1].

A projektfeladat végrehajtása szükségessé tette, a KUKA KR5 megfogó rendszer átalakítását, hogy alkalmas legyen anyagmozgatásra. Ennek érdekében egy Japán, Humphrey H040-4E2 típusú elővezérelt elektro-pneumatikus bistabil szelepre esett a választás, ami 2-től 7 bar-ig és $24 \mathrm{~V}$ egyenfeszültség mellett üzemel [1]. A vezérelhető szelep egy GRIP GmbH megfogóba került beépítésre. Ennek megvezérléséhez egy saját fejlesztésű vezérlőrendszer lett alkalmazva, a TiMo Board, ami alkalmas ipari pneumatikus/hidraulikus szelepek vezérléséhez, korábban kisebb gyártósori cellák vezérlésénél már bizonyított.

Mivel TiMo Board, kialakítása révén hálózatba kötve is programozható és felügyelhető, ezért az Ipar 4.0/IoT szempontokat figyelembe véve, egy saját Linux Disztribúciót hoztunk létre a Timotei-Roboticset, mivel a Linux alapú rendszerek a package és security frissítek miatt nagyobb védelmet élveznek a hálózatra kötött, beágyazott rendszereknél.

Az OS maga személyi számítógépekre telepíthető, amik rendelkeznek a minimális rendszerkövetelményekkel $(700 \mathrm{MHz}$ x64 CPU, 512 MB RAM, 8 GB HDD/SSD szabad hely). Esetünkben egy középkategóriás Notebook-ra került feltelepítésre. A TiMo Board másik alappillére a saját OS-n való komunikáció mellett egy Raspberry Pi B+ modell [2].

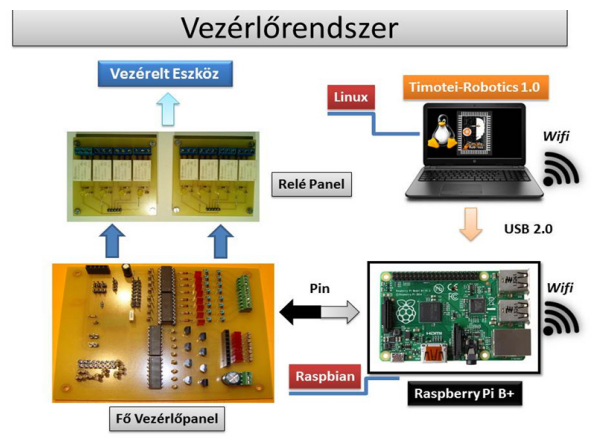

1. ábra. Programozható beágyazott rendszer

Amikor programozzuk a vezérlőpanelt (TiMo Borad), akkor a programot a Notebook-on a Timotei-Robotics OS-en írjuk, szabvány PLC létra diagramban, majd a megírás után generálunk egy programkódot, ami Raspberry Pi B+ -hoz kerül kiküldésre. A TiMo board vezérlő panel beépítésre került a KUKA KR5 ipari robot pneumatikus megfogó elektromos körébe, ami az alábbi ábrán látható:

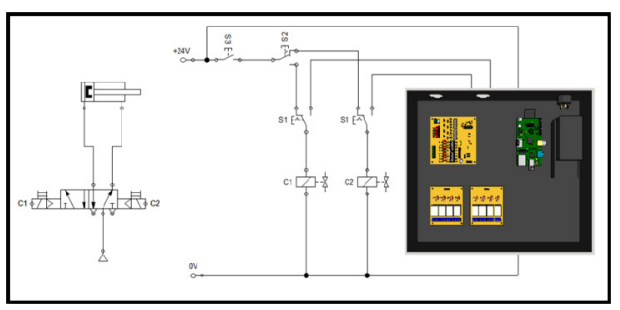

2. ábra. TiMo Board - KUKA KR5 megfogó 


\section{ARma \& OpenCV}

Ahhoz, hogy az Épületmechatronikai Kutatóközpontot, mint "Intelligens Tér" ként (iSpace) [4] tudjuk kezelni, szükség van vision szenzorra és képelemzési feladatokat ellátó részegységre.

A képelemzési feladatokat az OpenCV, Real-Time képelemző, platform független program látta el. Amibe integrálásra került az ARma extended könyvtár, így lehetőségünk nyílt $\mathrm{AR}$ alapú képelemzést végezni.

A kiterjesztett valóság más néven $\mathrm{AR}$, rendkívül komplex képelemzési feladat, mivel tényezők együttese kell, hogy megfeleljen a használatakor. Első körben el kell készíteni az adott 3D modellt, aminek részletességét a mindenkori poligon szám határozza meg. Ez a modell kerül beágyazásra egy QR-Code-ba, amiből az OpenCVARma [3] képes dekódolni a 3D modellt.

Az AR esetén a „Marker” -nek használt QR-Code koordináta rendszere határozza meg, hogy a korábban elkészített és kódba ágyazott 3D modell milyen pozícióban kerül leképezésre.

$$
U=\frac{d X}{d t}=\left(\frac{d Y}{d t}, \frac{d Y}{d t}, \frac{d Z}{d t}\right)^{T}
$$

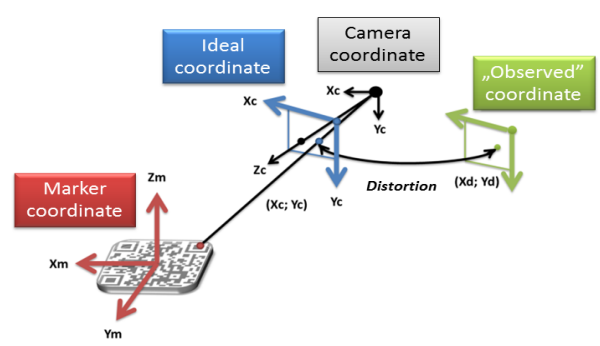

3. ábra. Kamera, objektum pozició detektálása

$\mathrm{Az}$ OpenCV-ARma teszthez elöször 2 MPx-es USB 2.0 kamerát alkalmaztunk. Továbbá a tesztkörnyezet a Robotlabor volt, mivel jól szabályozható fényviszonyokkal rendelkezik, ami kulcsfontosságú kritérium.

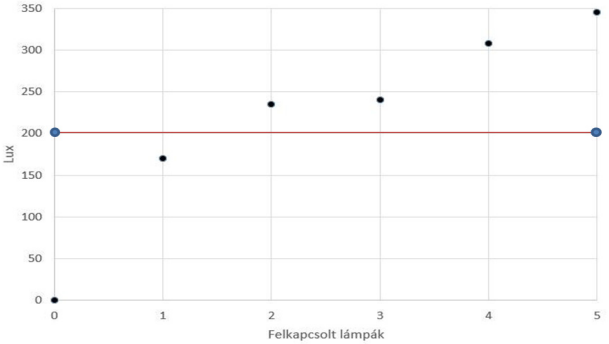

4. ábra. $L U X$ - mérés-detektálás függvényében

Az elvégzett mérések alátámasztották, hogy legalább 200 Lux feletti értéknek kell lennie az adott terület fényerősségének, hogy egy 2 MPx-es kamera is alkalmas legyen dekódolásra. A későbbi éles teszthez vision szenzornak egy 16 MPx-es, LinuxAndroid középkategóriás telefont választottunk.

Ezt követően megtervezésre/ megépítésre került egy mini AGV robot, ami könnyen újratervezhető, költséghatékony és kategorikusan a projektfeladat elvégzésére alkalmas.

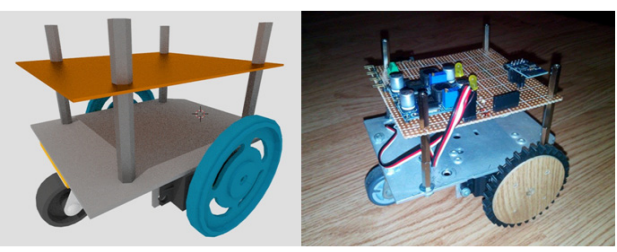

5. ábra. Mini $A G V$ prototipus robot

$\mathrm{Az}$ AGV prototípus áramkörében egy Arduino Nano, két LM2596 DC step-down konverter, két szervomotor, és egy ESP8266 Wi-Fi-Serial modul található [5].

\section{AGV AR virtuális navigáció}

A teszteléshez a Robotlabor lett kiválasztva, mint izolált és szabályozott környezet. Azért, hogy a területet iSpace-ként alkalmazhassuk, kinyomtatásra és elhelyezésre kerültek a QR-Codeok/Marker-ek. Az elhelyezett QR-Code-ok mindegyikre egyedi parancsot tartalmaz az AGV számára, és jól kategorizálhatóak, így az útvonalat könnyen kijelölhetjük számára. 


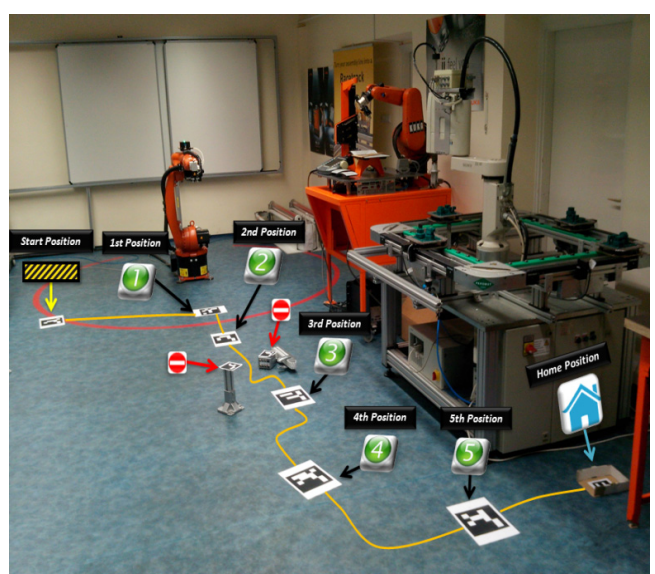

6. ábra. Robotlabor - "Intelligens Tér" (iSpace)

Az AGV meghatározott feladata az volt, hogy a QR-Code által meghatározott „Start” pozícióból a „Home” pozícióba jusson el, útba ejtve a „Pozíció 1-et, ahol a programban megadott ideig várakozik, míg a KUKA KR5 ipari robot megfogójába befogott és az általunk TiMo Board, PLC létrában programozott megfogó le nem teszi a szállítandó fém kockát az AGV-re, majd ezután, 2, 3, 4, és 5, pozíció markeret veszi célba. A „Tilos” jelzésű Markerekkel jelölt objektumokat pedig meghatározott távolságban kerüli el. Az AGV-n található Marker célja a jármü pozíciójának a meghatározása, mivel nem volt szükség külön helymeghatározó szenzor beépítésére.

A létrehozott rendszer komplex, mivel az IP kamera a Linux-Android telefon, aminek videostream-jét Wi-Fi-n keresztül sugároztuk egy zárt, saját hálózat számára. A hálózat csomópontját egy TP-LINK TL-841N Wi-Fi router képezte [6]. Erre csatlakozott az AGV, szintén vezeték nélkül és az OpenCV-ARma szoftvert futtató laptop is. Ha a hálózaton lévő okostelefon kamerájának látószögébe kerül valamelyik kód, akkor a laptop dekódolja a kódhoz rendelt textúrázott $3 \mathrm{D}$ modellt és parancsot, amit ezután az AGV kategorikusan végrehajt.

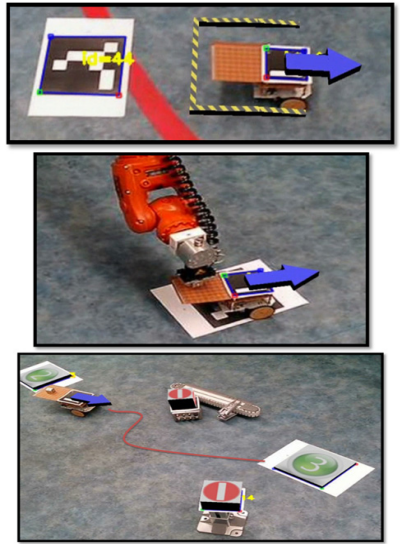

7. ábra. $A G V$ AR alapú navigáció

\section{Következtetések}

A létrehozott AR kiber-fizikai navigációs rendszer első teszt futtatását követően egyértelmüvé vált, hogy nincs szükség külön szenzorokra, az általunk kidolgozott AGV navigációs rendszer számára, mindössze hálózatra kötött IP kamerákra. Továbbá a kinyomatott kódok áthelyezésével újratervezhető/bővíthető az AGV útvonala. A kiépített rendszer új távlatokat nyithat meg az AGV robotok navigációjában, mivel nem igényel komolyabb beruházást és az ipari létesítmények jelentős hányada biztonságtechnikai szempontok miatt IP kamerákkal van felszerelve, így a rendszerünk könynyen és üzembiztosan integrálható/alkalmazható és minimális beüzemelési költségekkel jár.

\section{Szakirodalmi hivatkozások}

[1] G. Husi: Position Singularities and Ambiguities of the KUKA KR5 Robot - International Journal of Engineering Technologies, Vol.1, No.1, 2015

[2] https://www.raspberrypi.org/ (2017.01.10)

[3] http://opencv.org/ (2017.01.11)

[4] Hashimoto Hideki, Szemes Peter: Ubiquitous sensory intelligence Budapest, Magyarország, 2003.12.12-2003.12.14. pp. 73-86.

[5] https://www.arduino.cc/ (2017.01.12)

[6] http://www.tp-

link.com/hu/products/details/cat-9_TL-

WR841N.html (2017.01.14) 